\title{
The effects of binge-pattern alcohol consumption on orthodontic tooth movement
}

\author{
Cristiano Miranda de Araujoㄴ, Aline Cristina Batista Rodrigues Johann², Elisa Souza Camargo³, Orlando Motohiro Tanaka ${ }^{3}$
}

DOI: http://dx.doi.org/10.1590/2176-9451.19.6.093-098.oar

Objective: This study aimed to assess tissue changes during orthodontic movement after binge-pattern ethanol 20\% exposure. Methods: Male Wistar rats $(\mathrm{n}=54)$ were divided into two groups. The control group $(\mathrm{CG})$ received $0.9 \%$ saline solution, while the experimental group (EG) received $20 \%$ ethanol in $0.9 \%$ saline solution $(3 \mathrm{~g} / \mathrm{kg} / \mathrm{day})$. On the $30^{\text {th }}$ day, a force of $25 \mathrm{cN}$ was applied with a nickel-titanium closed coil spring to move the maxillary right first molar mesially. The groups were further divided into three subgroups (2, 14 and 28 days). Tartrate-resistant acid phosphatase and picrosirius were used to assess bone resorption and neoformation, respectively. Data were compared by two-way ANOVA, Tukey's HSD, Games-Howell and chi-square test. Significance level was set at 5\%. Results: There was a decrease in the number of osteoclasts in EG at day 28. The percentage of collagen showed no interaction between group and time. Conclusion: Binge-pattern 20\% ethanol promoted less bone resorption at the end of tooth movement, thereby suggesting delay in tooth movement.

Keywords: Tooth movement. Orthodontics. Bone remodeling.

Objetivo: objetivou-se avaliar as alterações teciduais decorrentes da administração de etanol a $20 \%$ no padrão binge, durante o movimento ortodôntico. Métodos: foram utilizados ratos Wistar machos $(\mathrm{n}=54)$, divididos em dois grupos, sendo Grupo Controle (GC), com administração de soro fisiológico a 0,9\%; e Grupo e Experimental (GE), com administração de etanol a $20 \%$ em soro fisiológico a $0,9 \%$, no volume de $3 \mathrm{~g} / \mathrm{kg} /$ dia. Após o $30^{\circ}$ dia de administração, foi aplicada força de $25 \mathrm{cN}$ com mola fechada de níquel-titânio para mover o primeiro molar superior direito para mesial. Os grupos foram subdivididos nos subgrupos 2, 14 e 28 dias, correspondendo ao número de dias de movimentação dentária. Utilizou-se as colorações de fosfatase ácida-tartarato resistente e picrosírius para avaliar reabsorção óssea e neoformação óssea, respectivamente. Os dados foram comparados por ANOVA a dois critérios, Tukey HSD e Games-Howell, ao nível de significância de 5\%. Resultados: verificou-se diminuição no número de osteoclastos no GE II no $28^{\circ}$ dia. A percentagem de colágeno não demonstrou alteração na interação grupo x tempo. Conclusões: o etanol no padrão binge a 20\% promoveu menor reabsorção óssea no final da movimentação dentária, sugerindo atraso na movimentação dentária.

Palavras-chave: Movimentação dentária. Ortodontia. Remodelação óssea.

${ }^{1} \mathrm{PhD}$ resident in Dentistry, Catholic University of Paraná (PUC-PR).

${ }^{2}$ Associate professor, School of Dentistry, PUC-PR.

${ }^{3}$ Full professor, School of Dentistry, PUC-PR.
How to cite this article: Araujo CM, Johann ACBR, Camargo ES, Tanaka OM. The effects of binge-pattern alcohol consumption on orthodontic tooth movement. Dental Press J Orthod. 2014 Nov-Dec;19(6):93-8. DOI: http:// dx.doi.org/10.1590/2176-9451.19.6.093-098.oar

Submitted: November 04, 2013 - Revised and accepted: April 02, 2014

" The authors report no commercial, proprietary or financial interest in the products or companies described in this article.

Contact address: Orlando Motohiro Tanaka Rua Imaculada Conceição, 1155 - Bairro Prado Velho CEP: 80215-901 - Curitiba/PR - Brazil

Email: tanakaom@gmail.com 


\section{INTRODUCTION}

Alcohol abuse affects approximately 14 million North Americans. ${ }^{1}$ Ethanol is the main component of alcoholic beverages, and it is considered to be toxic not only to vital organs, but also to hard tissues, such as bones. Chronic alcohol consumption is associated with pathological effects on bone and tissue integrity, which complicates post-injury or surgery repair processes in addition to acceleration of osteoblast apoptosis., ${ }^{2,3}$

Binge-pattern alcohol consumption in humans is characterized by excessive consumption within a short period of time, with approximately five or more drinks on a single occasion for men and four for women., ${ }^{4,5}$ According to Callaci et al, ${ }^{6}$ experimental binge-pattern ethanol consumption can be mimicked by administering ethanol injections four days a week, followed by three days during which no alcohol is administered. Intraperitoneal (IP) injections are well tolerated by rats and cause minimal stress. Another advantage of this route is that it achieves a high concentration of alcohol in blood and in a controlled environment. Additionally, it has minimal effects on rat's body weight.

Callaci et $\mathrm{al}^{7}$ administered 20\% binge-pattern ethanol in rats and found decreased mineral density in the vertebrae, both in cortical and cancellous regions, as well as decreased compressive strength. Similarly, they reported that treatment with $20 \%$ ethanol had varying effects on different bone regions, i.e., lumbar vertebrae proved more resistant than the tibia. Callaci et $\mathrm{al}^{6}$ also observed that, from the third week of binge-pattern 20\% ethanol exposure on, bone mineral density of the femur and lumbar spine decreased significantly.

Orthodontic tooth movement (OTM) is characterized by sequential reactions to biomechanical forces that induce changes in periodontal tissue and are related to bone remodeling by activation of alveolar bone resorption on the pressure side and consequent bone apposition on the traction side. ${ }^{9,10,11}$ Ethanol-induced imbalance between the processes of bone formation and resorption directly affect bone repair. ${ }^{15}$ To date, there have been no reports in the literature regarding the influence of ethanol on OTM.

Therefore, the objective of our study was to assess the tissue changes occurring during OTM in the periodontal ligament and alveolar bone adjacent to the mesial and distal areas of maxillary right first molar after administration of $20 \%$ ethanol. We particularly assessed bone resorption and neoformation.

\section{MATERIAL AND METHODS}

This project was approved by PUC-PR Ethics Committee on Animal Use. A total of 54 male, 9-week-old Wistar rats (Rattus norvegicus albinus), weighting approximately 300-350 g, was used. Temperature remained between $19{ }^{\circ} \mathrm{C}$ and $22{ }^{\circ} \mathrm{C}$ with a 12/12-hour light/dark photoperiod. The rats were provided with crushed food and water ad libitum. To observe changes in weight, the animals were weighed weekly with the aid of an electronic precision scale (Gehaka - BG 4001, São Paulo, Brazil).

The animals were randomly divided into two groups (27 rats per group): The control group (CG) received $0.9 \%$ saline solution in a volume similar to that given to the experimental group, whereas the experimental group (EG) received 20\% ethanol (w/v) in $0.9 \%$ saline solution $(3 \mathrm{~g} / \mathrm{kg} /$ day $) .{ }^{6}$ These groups were further subdivided into three subgroups $(2,14$ and 28 days; $n=9$ /group), which corresponded to the day of animal death after applying orthodontic force, so as to characterize the evolution of OTM over time.

Administration of solutions began 30 days before the orthodontic appliance was installed and continued until animal's sacrifice. It was performed intraperitoneally and designed so as to mimic binge drinking. Ethanol was administered four days a week, followed by three days of abstinence. ${ }^{6}$

The device used to induce OTM consisted of a nickel-titanium closed coil spring $\left(\mathrm{G} \& \mathrm{H}^{\circledR}\right.$ Wire Franklin, Indiana, USA) attached to maxillary right first molar and central incisors of all animals, which produced a $25-\mathrm{cN}$ reciprocal force.${ }^{14}$ Measurement of the force produced by the coil spring was standardized by means of a calibrated dynamometer (HaagStreit AG, Switzerland Koeniz, Switzerland). After initial activation, the coil spring was not reactivated during the experimental period; however, its position was checked on a daily basis.

The animals were sacrificed with an intraperitoneal overdose of anesthetic $(5.4 \mathrm{ml} / \mathrm{kg}$ ketamine). Then, the mandible of each animal was removed, dissected and sectioned at the midline. Right hemimaxilla 
remained in 10\% formaldehyde solution for 24 hours for proper fixation. After two months of demineralization, animals' maxilla was further fixed in 4.13\% ethylenediamine tetraacetic acid solution (Biotec Analytical Reagents, Pinhais, Brazil), processed and embedded in paraffin. A total of 15 cross-sections were cut on the cervical third of the mesiobuccal root of maxillary first molars with a microtome at $4 \mu \mathrm{m}$, the occlusal surface of the molar parallel to the microtome and $60-\mu \mathrm{m}$ intervals between sections.

The slides were stained with picrosirius and tartrate-resistant acid phosphatase (TRAP). Five sections were used for each technique.

Picrosirius staining was performed as follows: After deparaffinization in xylene, the sections were hydrated in ethanol and incubated for 1 hour in a solution of Sirius Red (Direct Red 80, diluted to $0.19 \%$ in saturated picric acid, Aldrich Chemical Company, Milwaukee, USA) at room temperature, followed by washing with distilled water, counterstaining with Harris hematoxylin, dehydrating in increasing alcohol solutions, deparaffinizing in xylene and mounting in Entellan.

For the TRAP technique, we used the TRAP Sigma 387A kit (Sigma-Aldrich Chemicals, St. Louis, Missouri, USA), following the manufacturer's recommendations.

Picrosirius-treated histological slides were assessed under light microscopy. Images were obtained using an Olympus BX-50 microscope (Olympus, Tokyo, Japan) equipped with Olympus U-Pot ${ }^{\circledR}$ polarized lens (Olympus, Tokyo, Japan) coupled to a Dino-Lite ${ }^{\circledR}$ microcamera (AmMo Electronics Corporation, New Taipei City, Taiwan) at a magnification of $100 x$. Images were analyzed with the Image Pro Plus morphometry program version 4.5 (Media Cybernetics, Rockville, Maryland, USA) to determine the percentage of areas of immature and mature collagen. ${ }^{13}$ Type I collagen (mature) appeared red-orange, while type III collagen (immature) was yellowish-green. ${ }^{15}$ The bone adjacent to the distal surface of the root was chosen for evaluation, as, during OTM, bone is deposited in the alveolar wall on the traction side. ${ }^{13}$

The TRAP-stained sections were used to identify osteoclasts and to determine bone resorption quantitatively. Thus, TRAP-positive multinucleated cells in the periodontal ligament adjacent to the alveolar bone were considered as functional osteoclasts. These cells were quantified ${ }^{16}$ by means of obtaining five images of the mesial region of the root, totaling an area of $942,813.00 \mu \mathrm{m}^{2}$ of the periodontal ligament. An Olympus BX-50 microscope (Olympus, Tokyo, Japan) coupled to a Dino-Lite ${ }^{\circledR}$ microcamera at $400 \mathrm{x}$ magnification. ${ }^{17}$ Images were analyzed with Image Pro Plus software, version 4.5 (Media Cybernetics, Silver Spring, Maryland, USA), using a counting grid. We calculated the mean of the five sections to obtain the average number of osteoclasts.

Reproducibility power was analyzed. Dahlberg error was less than $1.8 \%$, thereby indicating that the estimate of random error was reliable.

Statistical analysis was performed using SPSS software (version 16.0, SPSS IBM, Armonk, New York, USA). Significance level for all tests was set at 0.05.

To compare the mean values of dependent variables, in other words, the percentage of type I collagen in bone tissue and the number of osteoclasts according to the interaction between group and time, we initially tested the data for normal distribution and homogeneity of variances among the different treatments. To this end, Shapiro-Wilk test and Levene's test were used.

Since groups showed normal distribution $(\mathrm{P}>0.05)$, mean values were compared by means of two-way ANOVA (group and time) with full factorial design. When ANOVA revealed differences and when treatment presented homogeneity of variance, we performed Tukey's HSD test for multiple comparison. For heterogeneous variance, we employed Games-Howell multiple comparison tests.

\section{RESULTS}

\section{Bone resorption}

The interaction between group and time revealed statistically significant difference $(\mathrm{P}<0.05)$. EG showed a smaller number of osteoclasts than CG when they were compared on day 28 (Table 1, Fig 1).

\section{Bone neoformation}

When the percentage of type I collagen was assessed, no statistically significant difference $(\mathrm{P}>0.05)$ was observed based on group-time interaction (Table 1, Fig 2). 
Weight

We found statistically significant weight difference between EG and CG on day $2(\mathrm{P}<0.05)$ (Table 1).

\section{DISCUSSION}

Alcohol consumption during adolescence and young adulthood is considered an important public health issue in the United States. ${ }^{18,19}$ However, despite evidence showing that a significant number of adolescents and young people tend to binge drink ethanol, most studies about the effects of ethanol action on bone metabolism have used chronic consumption models. ${ }^{8}$ Based on these data, we decided to investigate binge pattern which is a more common pattern of alcohol consumption among teenagers and college students, ${ }^{19}$ an age group which often undergo orthodontic treatment.

The methods described in the literature have employed varying concentrations of ethanol and

Table 1 - Variables mean and standard deviation: Number of osteoclasts, percentage of type I collagen and weight variation in control (CG) and experimental (EG) groups.

\begin{tabular}{|c|c|c|c|}
\hline \multirow{2}{*}{ Groups/Variables } & \multicolumn{2}{|c|}{ Mean \pm SD } & \multirow{2}{*}{$\begin{array}{c}\text { Comparison } \\
\text { CGx EG }\end{array}$} \\
\hline & CG & EG & \\
\hline \multicolumn{4}{|c|}{ Number of osteoclasts } \\
\hline 2 days & $1.7375 \pm 2.05492$ & $2.6286 \pm 1.17716$ & 0.971 \\
\hline 14 days & $4.7250 \pm 3.24643$ & $3.8571 \pm 2.36492$ & 0.999 \\
\hline 28 days & $7.0000 \pm 3.92641$ & $2.1571 \pm 1.72516$ & $0.012^{*}$ \\
\hline \multicolumn{4}{|c|}{ Percentage of type I collagen } \\
\hline 2 days & $86.1425 \pm 8.48060$ & $66.1814 \pm 15.9878$ & 0.179 \\
\hline 14 days & $78.5175 \pm 17.6788$ & $70.1642 \pm 18.7859$ & 0.968 \\
\hline 28 days & $85.7328 \pm 9.10578$ & $75.8685 \pm 15.2132$ & 0.932 \\
\hline \multicolumn{4}{|c|}{ Weight variation } \\
\hline 2 days & $15.7863 \pm 4.25056$ & $6.0014 \pm 5.31286$ & $0.005^{\star}$ \\
\hline 14 days & $10.5050 \pm 22.8312$ & $14.1914 \pm 4.39931$ & 0.852 \\
\hline 28 days & $14.2486 \pm 2.22475$ & $6.1529 \pm 5.77777$ & 0.055 \\
\hline
\end{tabular}

$\star P<0.05$

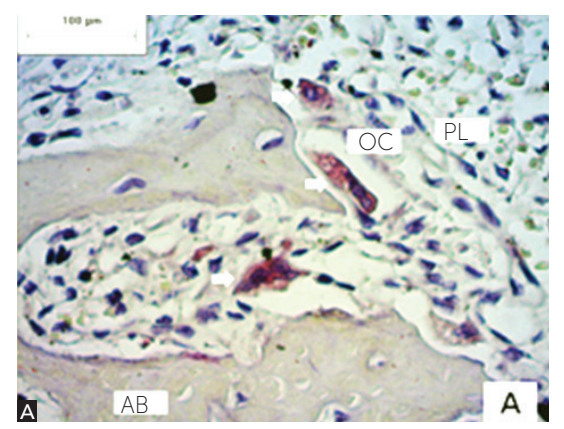

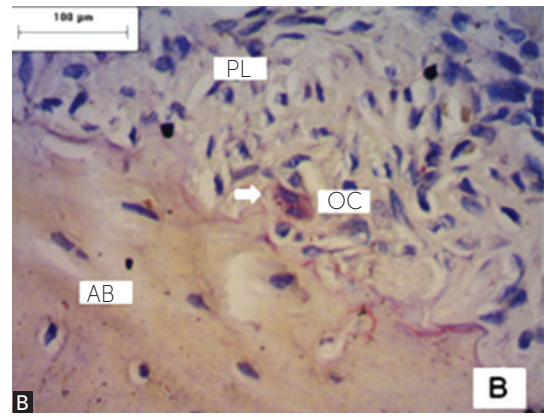



Figure 1 - Photomicrographs of histological slides in CG (A) and EG (B) on the $28^{\text {th }}$ day after orthodontic appliance installation. Fewer osteoclasts were observed in the EG on the side where pressure was applied to the periodontal ligament of the mesiobuccal root of the right maxillary first molar. AB: alveolar bone; PL: periodontal ligament; $O C$ : osteoclasts. White arrows indicate TRAP-positive cells (TRAP, magnification 400x).

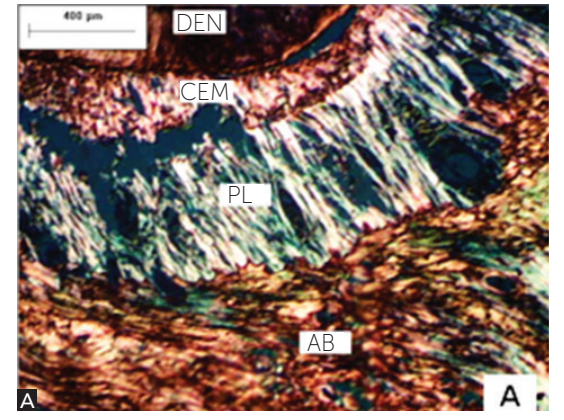

Figure 2 - Photomicrographs of histological slides on the distal surface of mesiobuccal root of right maxillary first molar in control (A) and experimental (B) groups on the $28^{\text {th }}$ day after orthodontic appliance installation. There were no statistically significant differences in the group-time interaction. DEN: dentin; CEM: cementum; PL: periodontal ligament; $A B$ : alveolar bone (picrosirius, magnification 100x) 
different application times to assess the effects of ethanol on bone tissue and neoformation. Studies on the effects of ethanol on bone tissue have used concentrations ranging from $5 \%$ to $20 \%$ for periods of 4 to 12 weeks. , $7,8,20,21$ No reports associating the effects of ethanol and OTM were found; thus, we used 20\% ethanol of which effects on bone neoformation are widely known. ${ }^{2,6,7,8,22}$

OTM is predominantly mediated by the periodontal ligament. For this reason, periodontal health is essential for OTM to occur without causing deleterious effects to the patient. Dantas et a ${ }^{23}$ stated that ethanol consumption is a risk factor for periodontal health as it promotes local inflammation in gingival tissues. Nevertheless, Liberman et $\mathrm{al}^{24} \mathrm{re-}$ ported a dose-dependent relationship between bone loss and ethanol consumption. They also found that low concentrations of ethanol do not significantly lead to alveolar bone loss. Conversely, high concentrations may aggravate bones loss, even in the absence of stainless steel ligature ties which may induce periodontal disease. Accordingly, Souza et a ${ }^{25}$ and Porto et $\mathrm{al}^{26}$ also detected the harmful potential of ethanol in periodontal bone tissues.

In the present study, we observed that on the $28^{\text {th }}$ day after the orthodontic appliance was installed, there was a decrease in the number of osteoclasts in the EG group $(\mathrm{P}<0.05)$ compared to the CG group. There have been reports that ethanol promotes increased resorptive activity; however, the maximal time of application in these studies was four weeks. ${ }^{6,7,8}$ Preedy et $\mathrm{al}^{27}$ assessed the influence of ethanol applied for more than four weeks, and found a decrease in urinary DPD excretion after six weeks of consumption. Accordingly, we observed a statistically significant decrease in the number of osteoclasts at day 28 , after six weeks of ethanol exposure. These changes suggest that OTM could be delayed by decreased bone resorption and that ethanol could influence osteoclast activity over time.

Approximately $90 \%$ of organic bone matrix consists of type I collagen degraded during bone resorption and replaced by immature fibers composed of type III collagen. ${ }^{16,24}$ Callaci et $\mathrm{al}^{6}$ assessed the effects of ethanol on bone metabolism and found an increase in type I collagen degradation and a corresponding decrease in bone mineral density.
Conversely, Maran et $\mathrm{al}^{25}$ found that there was no reduction in type I collagen. Similarly, we did not find differences in the percentage of type I collagen in alveolar bone $(\mathrm{P} \geq 0.05)$. These results suggest that ethanol does not influence the processes of collagen deposition and bone neoformation.

We observed statistically significant differences in weight $(\mathrm{P}<0.05)$ at day 2. EG II group showed greater weight variation than $\mathrm{CG}$. Lauing et $\mathrm{a}^{8}$ reported that factors such as animal health after intraperitoneal injection, reduced food intake of animals exposed to ethanol and the direct effect of ethanol on the ability of rats to transform dietary nutrients into body weight might have directly influenced the difference in weight gain between control and experimental groups.

The effects of ethanol on bone remodeling remain controversial, but the common hypothesis is that ethanol affects bone metabolism. Differences in variables such as age and time of ethanol consumption could explain discrepant results. In addition, no consensus has yet been reached on which factor, whether increased resorption or decreased neoformation, acts as the major mediator inducing bone loss as a result of ethanol consumption. ${ }^{12}$ Nevertheless, we found that ethanol promoted an imbalance in bone resorption. Additionally, its effects must be thoroughly considered from an orthodontic viewpoint, since tooth movement is a bone-dependent process.

Further studies should be performed in order to find out how ethanol affects bone remodeling. In the present study, we showed that 20\% ethanol influences bone metabolism due to decreasing the number of osteoclasts when an orthodontic force is applied. Caution should be taken when applying orthodontic force in individuals who binge drink ethanol, as this substance can delay bone remodeling processes and possibly increase orthodontic treatment total time.

\section{CONCLUSION}

Ethanol does not influence the processes of collagen deposition or bone neoformation.

Binge-pattern 20\% ethanol consumption promotes a decrease in resorption at the end of OTM.

Ethanol affects bone metabolism, thereby suggesting delay in OTM. 
1. Grant BF, Dawson DA, Stinson FS, Chou SP, Dufour MC, Pickering RP. The 12-month prevalence and trends in DSM-IV alcohol abuse and dependence: United States, 1991-1992 and 2001-2002. Drug Alcohol Depend 2004:74:223-34

2. Soares EV, Favaro WJ, Cagnon VH, Bertran CA, Camilli JA. Effects of alcohol and nicotine on the mechanical resistance of bone and bone neoformation around hydroxyapatite implants. J Bone Miner Metab. 2010:28:101-7.

3. Klein RF. Alcohol-induced bone disease: impact of ethanol on osteoblast proliferation. Alcohol Clin Exp Res. 1997;21(3):392-9.

4. Wezeman FH, Juknelis D, Himes R, Callaci JJ. Vitamin D and ibandronate prevent cancellous bone loss associated with binge alcohol treatment in male rats. Bone. 2007:41(4):639-45.

5. Wechsler $\mathrm{H}$, Nelson TF. Binge drinking and the American college student: what's five drinks? Psychol Addict Behav. 2001;15(4):287-91

6. Callaci JJ, Juknelis D, Patwardhan A, Sartori M, Frost N, Wezeman FH. The effects of binge alcohol exposure on bone resorption and biomechanical and structural properties are offset by concurrent bisphosphonate treatment. Alcohol Clin Exp Res. 2004;28(1):182-91.

7. Callaci JJ, Juknelis D, Patwardhan A, Wezeman FH. Binge alcohol treatment increases vertebral bone loss following ovariectomy: compensation by intermittent parathyroid hormone. Alcohol Clin Exp Res. 2006:30(4):665-72.

8. Lauing K, Himes R, Rachwalski M, Strotman P, Callaci JJ. Binge alcohol treatment of adolescent rats followed by alcohol abstinence is associated with site-specific differences in bone loss and incomplete recovery of bone mass and strength. Alcohol. 2008:42(8):649-56.

9. Macapanpan LC, Weinmann JP. The influence of injury to the periodontal membrane on the spread of gingival inflammation. J Dent Res. 1954;33(2):263-72

10. Heller IJ, Nanda R. Effect of metabolic alteration of periodontal fibers on orthodontic tooth movement. An experimental study. Am J Orthod. 1979:75(3):239-58

11. Hamaya M, Mizoguchi I, Sakakura Y, Yajima T, Abiko Y. Cell death of osteocytes occurs in rat alveolar bone during experimental tooth movement. Calcif Tissue Int. 2002;70(2):117-26

12. Dai J, Lin D, Zhang J, Habib P. Smith P, Murtha J, et al. Chronic alcohol ingestion induces osteoclastogenesis and bone loss through IL-6 in mice. J Clin Invest. 2000 Oct;106(7):887-95

13. Retamoso L, Knop L, Shintcovsk R, Maciel JV, Machado MA, Tanaka O. Influence of anti-inflammatory administration in collagen maturation process during orthodontic tooth movement. Microsc Res Tech. 2011;74(8):709-13.

14. Hashimoto M, Hotokezaka H, Sirisoontorn I, Nakano T, Arita K, Tanaka $M$, et al. The effect of bone morphometric changes on orthodontic tooth movement in an osteoporotic animal model. Angle Orthod. 2013:83(5):766-73
15. Borges LF, Gutierrez PS, Marana HR, Taboga SR. Picrosirius-polarization staining method as an efficient histopathological tool for collagenolysis detection in vesical prolapse lesions. Micron. 2007:38(6):580-3. Epub 2006 Nov 13

16. Marquezan M, Bolognese AM, Araujo MT. Effects of two low-intensity laser therapy protocols on experimental tooth movement. Photomed Laser Surg. 2010;28(6):757-62.

17. Braga SM, Taddei SR, Andrade Jr I, Queiroz-Junior CM, Garlet GP, Repeke CE, et al. Effect of diabetes on orthodontic tooth movement in a mouse model. Eur J Oral Sci. 2011:119(1):7-14

18. Naimi TS, Brewer RD, Mokdad A, Denny C, Serdula MK, Marks JS. Binge drinking among US adults. JAMA. 2003;289(1):70-5

19. Windle M. Alcohol use among adolescents and young adults. Alcohol Res Health. 2003;27:79-85

20. Lima CC, Silva TD, Santos L, Nakagaki WR, Loyola YC, Resck MC, et al. Effects of ethanol on the osteogenesis around porous hydroxyapatite implants. Braz J Biol. 2011;71(1):115-9.

21. Sampson HW, Gallager S, Lange J, Chondra W, Hogan HA. Binge drinking and bone metabolism in a young actively growing rat model. Alcohol Clin Exp Res. 1999:23(7):1228-31

22. Volkmer DL, Sears B, Lauing KL, Nauer RK, Roper PM, Yong S, et al. Antioxidant therapy attenuates deficient bone fracture repair associated with binge alcohol exposure. J Orthop Trauma. 2011:25(8):516-21

23. Dantas AM, Mohn CE, Burdet B, Zorrilla Zubilete M, Mandalunis PM, Elverdin JC, et al. Ethanol consumption enhances periodontal inflammatory markers in rats. Arch Oral Biol. 2012:57(9):1211-7

24. Liberman DN, Pilau RM, Gaio EJ, Orlandini LF, Rosing CK. Low concentration alcohol intake may inhibit spontaneous alveolar bone loss in Wistar rats. Arch Oral Biol. 2011;56(2):109-13

25. Souza DM, Ricardo LH, Kantoski KZ, Rocha RF. Influence of alcohol consumption on alveolar bone level associated with ligature-induced periodontitis in rats. Braz Oral Res. 2009;23(3):326-32.

26. Porto AN, Semenoff Segundo A, Vedove Semenoff TA, Pedro FM, Borges $\mathrm{AH}$, Cortelli JR, et al. Effects of forced alcohol intake associated with chronic stress on the severity of periodontitis: an animal model study. Int J Dent. 2012;2012:465698

27. Preedy VR, Sherwood RA, Akpoguma Cl, Black D. The urinary excretion of the collagen degradation markers pyridinoline and deoxypyridinoline in an experimental rat model of alcoholic bone disease. Alcohol Alcohol. 1991;26(2):191-8

28. Eriksen EF, Charles P, Melsen F, Mosekilde L, Risteli L, Risteli J. Serum markers of type I collagen formation and degradation in metabolic bone disease: correlation with bone histomorphometry. J Bone Miner Res. 1993:8(2):127-32.

29. Maran A, Zhang M, Spelsberg TC, Turner RT. The dose-response effects of ethanol on the human fetal osteoblastic cell line. J Bone Miner Res. 2001;16(2):270-6. 